\title{
On the history of a subterranean geopolitics
}

\author{
Ian Klinke (University of Oxford)
}

\begin{abstract}
Geopolitics has in recent years been framed as a flat discourse whose cartographic obsessions prevent it from appreciating both the vertical dimension in which statecraft and armed conflict operate as well as the earth's geologic agency. This assessment, I argue, is based on an incomplete reading of the geopolitical tradition. A journey through the history of geopolitics reveals that whilst thinkers like Alfred Mahan, Halford Mackinder and Carl Schmitt displayed a tendency for flat earth thinking, it was the German political geographer Friedrich Ratzel (1844-1904) who developed a rich tapestry of terms to theorise the power and politics of geology and the underground. The advent of large scale conventional and later nuclear bombing in the 1940 prompted geopoliticians on both sides of the Atlantic to become increasingly interested in the 3-dimensionality of the struggle for space. This paper suggests the need for a dialogue between the intellectual history of geopolitics and the growing literatures on geopower and vertical geopolitics.
\end{abstract}

\section{Notes from the geopolitical underground}

A new enthusiasm has taken hold of the geographical imagination. Travel writers and adventurers are taking us into the realm beneath our feet, making their readers feel, smell and envision the bowels of the earth, from subterranean caves to mineshafts, from ancient catacombs to submerged nuclear missile bases. There is, or so we are made to believe, a primeval connection between the human and the humus. A burrowing species, Robert MacFarlane argues in the his 2019 Underland: A deep time journey, humans use the underground to shelter memories or precious matter, yield information and natural resources and bury what they wish to dispose of - be it human corpses, secrets or toxic substances. Whether celebrated as a dark place of perverse enlightenment (Hunt, 2019), enjoyed as place of hidden exuberance (Garrett, 2013) or read through a morbid romanticism (MacFarlane, 2019), there is no doubt that the underground is erupting into our surface-level imaginaries.

Something not entirely dissimilar seems to have happened elsewhere, too. For more than a decade now, studies of geopolitics, territory, urban life, colonialism and modern warfare have drawn our attention to the vertical dimension, to what happens below and above the earth's surface (Adey, Whitehead and Williams, 2013; Elden, 2013a; Graham, 2004; 2016; Scott, 2008). Geopolitics, in particular, is accused of constructing a flat world of two-dimensional areas, which have neither height, depth nor volume, thus limiting an understanding of how power operates above and beneath hegemonic cartographies of state power. Attention to volume and verticality has resulted in a fascinating array of studies which have addressed the geography of vertical violence, particularly the history of aerial bombardment (Gregory, 2011a), nuclear war (Farish, 2004; MacDonald, 2008) and drone warfare (Gregory, 2011b; Shaw, 2016). Often under the banner of a 'subterranean geopolitics' (Squire and Dodds, 2019), there is now an equally rich body of case studies which has explored mining and resource extraction (Childs, 2018; Valdivia, 2015), subterranean and subaquatic pipelines (Barry and Gambino, 2019; Murrey, 2015), bunkered architecture (Klinke, 2018; Garrett and Klinke, 2019), tunnels (Slesinger, 2018; Zhang, 2018) as well as technology which seeks to make the earth transparent (Bishop, 2012). 
Not all of these contributions have argued along similar lines. As Slesinger points out, this growing literature has fallen into two broad camps, the first of which has treated 'volumetric space [] as a vector through which political rational calculations are spatialized', whilst the second has approached it 'as an elemental volume made up of a materiality that exceeds and constrains actors' agencies to manipulate the earthly volume' (Slesinger, 2018: 3; see also Barry and Gambino, 2019). A further divide can be identified, particularly in work which takes the vertical into airspace, between those who seek to understand military power as exercised 'from above' (Graham, 2004) and those who have attempted to glance back at military violence 'from below', whether through radar or the naked eye (Fluri, 2011; Williams, 2013).

What unites all of these strands, however, is the sometimes tacit, but often explicit, idea that geopolitics was long a fundamentally flat and two-dimensional discourse which is only now appearing, in the eye of critical geographers, in 3D. In this vein, Valdivia (2015: 1425) marks out the subterranean as an as yet 'understudied geopolitical space', whilst Graham complains that '[i]n geography, especially, territory, sovereignty and human experience have long been flattened by a paradoxical reliance on flat maps - and, more recently, aerial and satellite images - projected or imagined from the disembodied bird's or God's eye view from high above' (Graham, 2016: 1). In making similar arguments, many proponents of this vertical turn (see Graham, 2004; 2016; Adey, Whitehead and Williams, 2013: 1; Elden, 2013a; Squire, 2016: 547; Williams, 2013) have in fact taken their cue from a short article written by the architectural scholar Eyal Weizman in 2002. In this piece, Weizman, who has since fleshed out in more detail the contours of a geopolitics that is attuned to the vertical (Weizman, 2007), claims the following:

'Geo-politics is a flat discourse. It largely ignores the vertical dimension and tends to look across rather than to cut through the landscape. This was the cartographic imagination inherited from the military and political spatialities of the modern state. Since both politics and law understand place only in terms of the map and the plan, territorial claims marked on maps assume that claims are applicable simultaneously above them and below' (Weizman, 2002).

Picking up from Weizman, Elden suggests a broader reading of the 'geo' in geopolitics. Geopolitics, he argues,

'has tended to become conflated with global politics or political geography writ large. But could we turn this back to thinking about land, earth, world rather than simply the global or international?' (Elden, 2013a: 49).

What is at stake here is thus a richer comprehension of the technological, lively and elemental matter that constitutes world politics (see also Dittmer, 2014; 2017; Peters, Steinberg \& Stratford, 2018). Inspired by various new materialisms, this more-than-human geopolitics opens up, at least to Elden and others, the possibility of a dialogue between geopolitics and earth systems processes (see Childs, 2018; Clark, 2013a; Dalby, 2013). It is worth noting that possibilism, the idea that geologic and climatic limits on human agency are crucial but not insurmountable, has become an increasingly popular alternative to the social constructivism popular in the $1990 \mathrm{os}$ and 2000s (Dalby, 2013; Dodds, 2019).

Again, not everyone is arguing the same thing here. Whilst some studies remain wedded to a Foucaultian preoccupation with governmental practices, others have found inspiration in Elizabeth Grosz's concept of geopower and Gilles Deleuze and Félix Guattari's geo-philosophy, both of which seek to excavate the inorganic and inhuman forces that subtend and provoke organic life and the political forms it takes in human societies throughout history (Grosz, 2012; Deleuze \& Guattari, 1994). Crucially, it is argued, that these forces cannot simply be approached either as a social construction or as an object of governmental practices (Clark, 2013a; 2017; Grosz, Yusoff and Clark, 2017). As Clark posits, a Foucauldian approach breaks down once it is 
confronted with the pre-political 'realms of the mineral, the lithic, the planetary, the cosmic' (Clark, 2013a: 48). He wants us to look down not just into the mineshafts and other man-made underground structures, but into the compositional layering of the earth itself. Clark traces the rise and fall of philosophical interest in the earth's stratification in the second half of the $18^{\text {th }}$ century and argues that it is now time to unravel anew the dependency of human society on transitions in the earth system (Clark, 2017). When placed in relation to the cosmic and geologic forces that function as the backdrop for all life, the limitations of human agency come into vision.

I argue in this essay that the idea of geopolitics as a flat and two-dimensional discourse is an oversimplification. The emerging literature on vertical and subterranean geopolitics, I suggest, would benefit from a re-reading of over a century of classical geopolitical writing, analytically and politically problematic as this genre may be. As I will show in what follows, the 2D thesis applies only to some, albeit crucial, traditions of geopolitical writing, particularly those associated with the thought of Alfred Mahan, Halford Mackinder and Carl Schmitt. It is in the geographical writing of others, such as Friedrich Ratzel and Karl Haushofer, as well as in the work of a number of cold war era military strategists, that a more vertical geopolitics, attentive not just to the earth as an ideological device (as in 'blood and soil' nationalism) but to geology and the subterranean built environment, can be found. I conclude by discussing the implications of this finding.

\section{Discworld theory}

When contemporary Anglophone geographers explore the origins of geopolitics, they tend to turn to the American naval officer and strategist Alfred Mahan and the British geographer Halford Mackinder (Flint, 2012; Ó Tuathail, 1996). Both men were passionate imperialists and wanted their ideas to shape the fortune of their respective nations. Given that Mahan and Mackinder are widely thought of today as theorists of sea power, it might seem unsurprising that they operated largely with a horizontal geopolitical imagination, which emphasised boundaries and networks that could be represented cartographically. And yet, it is worth illustrating the way in which they neglected and, in the case of Mackinder, actively resisted a vertical geopolitics. It is in this tradition of late $19^{\text {th }}$ and early $20^{\text {th }}$ century thought, which remains popular to this day, that we can find the clearest confirmation of the $2 \mathrm{D}$ thesis.

Alfred Thayer Mahan (1840-1914) was a naval officer, President of the US Naval War College and a vocal proponent of US naval expansion. Mahan, who would later lend his name to a class of US navy destroyers, argued in his seminal 1890 The Influence of Sea Power upon History that global hegemony depended on the control of maritime trade flows, which had to be ensured by naval power. Mahan wanted to understand the 'elements of sea power', which he broke down into the geographical positon, physical confirmation, extent of territory, number of population, character of the people and character of the government of different states (Mahan, 1890[1980]: 33). A proponent of free trade, Mahan thought of the sea as a wide common that was criss-crossed by vital trade routes. He was interested in seaboard length, the number and quality of harbours, the distance between these harbours as well as the role of straights and canals - but not in what happened beneath the earth's surface. Deep sea exploration was only in its infancy by the time Mahan published his most significant work and whilst submarine technology was being pioneered in Mahan's day, submarines were only properly introduced in 1914, the year of Mahan's death. The first airstrikes had been carried out a few years before his death, but they had not impacted the thinking of a man who had a tendency to look back to $17^{\text {th }}$ and $18^{\text {th }}$ century military history rather than to the emergent future of military technology that was already making itself felt in his days. Airspace, geology or the political implications of manmade subterranean structures were of little interest to him. 
A British academic, occasional explorer and briefly a Member of the House of Commons, Halford Mackinder (1861-1947) was very much concerned with the advent of new transport technology. Whereas his contemporary Mahan had written in detail about the rise of the steamboat (whilst neglecting the other aforementioned technological innovations), it was the spread of railway technology that captivated Mackinder. He famously argued in his heartland thesis that the end of the age of exploration and the advance of railway technology was tipping the global balance from sea to land power (Mackinder, 1904). Although a materialist with a keen interest in the impact of physical geography on world history, Mackinder was not one to think geopolitics in vertical terms. Indeed, Mackinder's world was one in which the crucial spaces were either agentic territorial states, less agentic states which performed functions for other and more powerful states (as bridgeheads etc.) or large continental-scale two-dimensional areas that were declared as being of different degrees of strategic importance (the heartland, the outer crescent, the North Atlantic etc.) (see Mackinder, 1904; 1919).

Though concerned with climatic conditions and the distribution of natural resources, Mackinder's materialism was primarily of a horizontal kind. If we get a sense of the vertical in Mackinder, it is only in his elevation above geographic space in a God-like position, either as a political geographer who observed an objectified map, or as an explorer of Mount Kenya (Mackinder, 1900; see also Kearns 2009, Ó Tuathail, 1996). His 1919 book Democratic Ideals and Reality noted in passing how humans had carved the rocks along the river Nile into 'cavernous temples and tombs' but Mackinder failed to move beyond a surface-level analysis of these spaces (Mackinder, 1919: 31). A 1943 paper hinted at the possibility of a subterranean imaginary when he spoke of the 'rich soil for cultivation and of ores and fuels for extraction' that lay 'upon and beneath the Heartland', but again, this thread was not developed (Mackinder, 1943: 603-4). Elsewhere in the article, Mackinder announced that he remained unconvinced by recent claims that the rise of aerial warfare constituted a challenge to his binary geopolitics of land and sea power.

"Some persons today seem to dream of a global air power which will "liquidate" both fleets and armies. I am impressed, however, by the broad implications of a recent utterance of a practical airman: "Air power depends absolutely on the efficiency of its ground organization." That is too large a subject to discuss within the limits of this paper. It can only be said that no adequate proof has yet been presented that air fighting will not follow the long history of all kinds of warfare by presenting alternations of offensive and defensive tactical superiority, meanwhile effecting few permanent changes in strategical conditions' (602).

Although it may seem that both Mahan and Mackinder's preoccupation with the flat surfaces of the oceans made it difficult for a more vertical imagination to emerge in their writing, it is important not to oversimply their position. For although both men are often thought of as having argued for the superiority of sea over land power, both were in fact concerned about the possibility of a large continental power emerging on the Eurasian landmass.

It is also not simply enough to conclude that Mahan and Mackinder's two-dimensional worldview must have been the expression of a specifically Anglo-American geopolitics, which would perhaps, as the German spatial thinker and Nazi jurist Carl Schmitt (1888-1985) implied, been the outgrowth of a rootless liberalism that he saw as inherent in the nature of sea power itself. For Schmitt, sometimes (rightly) associated with the German tradition of geopolitical thought (Elden, 2010; Werber, 2014), was himself a flat thinker of geopolitics, preoccupied with the surface-level interplay of land and sea power and the production of political boundaries. Schmitt did toy with an elemental understanding of geopolitics in his 1942 Land and sea: A world-historical mediation, which chimes interestingly with contemporary elemental readings of the geopolitical (Peters, Steinberg \& Stratford, 2018; Squire, 2016), and which would have allowed him to think perhaps in more volumetric and materialist ways. And yet, his work does 
little to further a vertical geopolitical imaginary. An interest in the earth-as-element and in landoriented forms of human existence notwithstanding, his geography remains concerned primarily with horizontal fields of vision and the effects on collective consciousness brought about by spatial revolutions such as the world's first circumnavigation. Although Schmitt was grappling with the ascent of air power (and returned to this in his 1950 Nomos of the earth), he declared that the conquest of the air was in fact an entry into the elemental age of fire, which had been heralded by the rise of the explosive motor and the aerial bombardment of densely populated urban spaces (Schmitt, 1942[2015]: 91). By collapsing the vertical into the elemental, Schmitt too resisted the vertical.

We will not dwell on this flat earth imaginary any further, but it is important to note that it did not simply disappear in the 1940s. Crucial works which sought to salvage geopolitics from its association with National Socialism (Bowman, 1942), popularised environmental thinking in the early Cold War (Kennan, 1947), or thought through nuclear strategy in a geopolitical vein (Kissinger, 1957[1969]) continued to be disinterested in the subterranean. And where the likes of Mahan, Mackinder and Schmitt remain sources of inspiration for contemporary geopolitical writing today, we see again a two-dimensional imaginary. And yet, elsewhere there had developed by the turn of the $2 \mathrm{O}^{\text {th }}$ century a different tradition of geopolitical thought, one very much entranced by the underground.

\section{Friedrich Ratzel and the subterraneans}

In order to appreciate a second and significantly more vertically infused strand of geopolitical thought, we must turn to Friedrich Ratzel (1844-1904), a German zoologist and geologist turned geographer. Although Ratzel did not use the term geopolitics himself, he is often seen, alongside Mahan and Mackinder, as one of the founders of the geopolitical tradition and is usually credited for having popularised the concept of Lebensraum (living space). It was Ratzel's follower Rudolf Kjellén who coined the term 'geopolitics' (Kjellén, 1920) and Ratzel's disciple Karl Haushofer who established the school of German geopolitics (Geopolitik) in Ratzel's name. Geopolitik would have a formative impact on national socialist ideology during the 1920 (Klinke and Bassin, 2018; Smith, 1980).

And yet, there is more to Ratzel than his impact on the rise of fascism in the interbellum. Ratzel was a vitalist who believed in the insatiable creativity of all life as well as the inseparability of the organic from the inorganic realm (monism) (Klinke, 2019). Human life was but a grain of dust compared to the cosmic and geologic forces that had made it appear. Like many contemporary geographers, Ratzel tried to understand the relationship between the earth system and human society. He wrote at great length not just on matters of biogeography (he was an admirer of Charles Darwin and had been lectured by Ernst Haeckel), but on physical geography and geology, too. Ratzel was not the first German thinker to combine an interest in geology and politics (Elden 2013b), but he was unique in thinking of geology and physical geography as auxiliary to human geography and history. Indeed many of his books featured chapters on geology (see in particular Ratzel, 1881; 1902). Even though he recognized that geographers were rarely taken seriously by geologists, he believed that geography could fill the disciplinary gap between geology and history by navigating between 'shallow' historical and 'deep' geological time (Ratzel, 1891[1912]): V, 7). And yet, geology, history and geography were not just disciplines to him which happened to have the same object of analysis (the earth) but different perspectives onto this object of analysis (Natter, 2005). Similarly, Ratzel's political geography could compete with political science and sociology for the interpretive supremacy over the state. For states, according to Ratzel, behaved like organisms which struggled for survival over limited resources in ways that called for a holistic 'geographical' perspective that could appreciate the 'groundedness' of social processes. 
Like Mahan and Mackinder, Ratzel too was mesmerized by naval power and vocally supported the expansion of the German navy (Ratzel, 1900[1911]). And whilst his analysis of the history of European sea power was mostly two-dimensional, he had a noticeable interest in deep sea exploration and would frequently refer to the abundance of marine organisms that found living space even in this most uninhabitable of environments (Ratzel, 1898[1906]). A crucial level of analysis for him was the biosphere, understood in fundamentally three-dimensional ways to incorporate all life from the highest mountains down to the deepest seabed. His conceptual language of habitat and colonisation applied to human and non-human life alike: the termite hill and the beehive were as much epiphenomena of the struggle for life as urban agglomerations or the colonial acquisitions of European powers in sub-Saharan Africa (Ratzel, 1901[2018]: 11).

Much like Alexander von Humboldt before him (Anthony, 2016), Ratzel's writing was moreover underwritten by an interest in what happened below the earth's surface. From an early age on, he had fanaticised about mythical creatures which might exist beneath the earth's crust and had vigorously collected fossils. His work would frequently refer to processes of fossilisation to discuss the nature of space and time. Ratzel's contemporaries even named an Arctic earthworm after him - enchytraeus ratzeli. Whilst his ethnological work would examine caves and grottos which had been used for human habitation and social rituals, his political writing speculated about a cultivation of the African drylands through reservoirs and drill pipes (Ratzel, 1884: 20). For Ratzel was not just a pan-German nationalist who had volunteered to fight in the 1870-71 Franco-Prussian war, but a keen promoter of German colonialism in Africa.

All life, human and non-human, Ratzel argued, was fundamentally earthbound in that it depended on the earth for resources and was molded by climatic conditions. He acknowledged in the second edition of his Anthropogeographie that there was 'something mysterious and sometimes frightening' in 'the power of the soil', which 'emerged from great depth through layers of history into contemporary life in all its richness' (Ratzel, 1891[1899]: 76). Ratzel thus developed an approach which was interested in the limits that the earth placed on human agency, its ability 'to annihilate the seeming freedom of man' (ibid). 'True realpolitik' as a mode of statecraft thus had to have 'a strong geographical core', he felt (Ratzel, 1891[1899]: 76). To the degree that the planet's climate was shaped by geologic forces and the climate itself had a direct influence on the diverse formation of human societies, Ratzel's political geography was necessarily devised as a 'geologic politics' (Clark, 2013b).

Despite the environmentally determinist streak that had underwritten his earlier work, Ratzel's worldview, especially in the later stages, was in fact more complex than is often acknowledged. In the final years of his career he had become increasingly interested in the interaction (Wechselwirkung) of the earth system and human life. Human life had the ability to make nature its servant, but there were limits imposed on this: ultimately human societies were earthbound. Humanity, Ratzel claimed, could 'raise its head aloft in pure ether, but its feet must ever rest on the ground, and the dust must return to the dust' (Ratzel, 1896: 3). At the same time, he was keen to show that the earth's agency was limited. Ratzel was skeptical for instance of the idea that external events had destroyed the entire flora and fauna on earth, by fire or by water, at the end of each geological era. 'Geologic catastrophes [did] not intervene profoundly into human history', he argued (Ratzel, 1890: 228). Too great was the discrepancy between what he deemed to be the slow processes of deep geologic time and the rapid transformations that could be observed in shallow historic time. Ratzel was convinced that 'no species or race', not even the dinosaurs, had 'suddenly died off', but had slowly been moved into spaces with poorer living conditions (Ratzel, 1901[2018]: 75). In consequence, he saw nature and society as being in a cosmic balance: Whilst he was eager to emphasise the limits that knowledge of physical geography could bring to his political geography (Ratzel, 1897[1923]: 542) and warned against an assumption of simple causality between geological agency (volcanic eruptions and earthquakes in particular) and national character, he wanted to understand the connection 
between the density of species and the general density of life' and 'peculiarities that must have geological causes' (Ratzel, 1901[2018]: 70). Ratzel was moreover intrigued by how fear of volcanic eruptions had proven a fertile ground for certain social norms - such as superstition - in some of the earth's more geologically volatile regions (Ratzel, 1882: 399). In 1872, he had himself ascended Mount Vesuvius and peered down into its crater only shortly after its eruption. Mesmerised by the occasional rumbling of the earth, he had gazed at lava streams and waded through ash until his soles burnt (Ratzel, 1873: 227-9). Ratzel's account is particularly interesting in highlighting the aesthetics of volcanically interested travel writing that stood at the inception of the modern geopolitical imagination (Hawkins, 2018).

Mackinder too had been attracted to geology and had emphasised that the 'Industrial Revolution of English history could not have been accomplished without the Hercynian Revolution of geology, for the coal upon which the one change rested was preserved in the process of the other' (Mackinder, 1902: 357). Ratzel sought to develop a more systematic language that could be used to understand human processes in a geologic register. In the second volume of his Anthropogeographie (1891), he argued that the names of human settlements and even language itself were stratified and could be excavated not unlike layers of sediment. Tracing what he referred to as the 'fossilisation of language', he proposed that 'in the same way as the geologist knows his [sic] index fossils, the existence of which guarantees the presence of a certain geological horizon, so can particular place names tell us about the former presence of a particular Volk in a region where linguistic traces have been preserved' (Ratzel, 1891[1912]): 348). The great Migration Period of $4^{\text {th }}-6^{\text {th }}$ centuries AD (Völkerwanderungen) had to his mind left 'magma' behind (Ratzel, 1882: 123). This was not a mere linguistic game for Ratzel, for he noted how volcanic activity had impacted on place names over time (353). Elsewhere he was fascinated by the speed at which organic life could blossom on volcanic soil after an eruption which had killed over 4,00o humans on Java in 1837. Fossils too were crucial to Ratzel's logic of living space, which he saw in the same way in the animal and plant kingdom as when it came to the rise and fall of states:

'We come to the same conclusion observing geological evidence for the retreat of old species and the progress of new ones. Clearly, the limitation of living space on earth demands that an old species vacate the space that a new one needs to develop. In this sense, new creation and progress presuppose retreat and demise' (Ratzel, 1901[2018]: 74)

Whilst Ratzel recognised the limitations of applying a geologic timescale to the much more recent phenomenon of human life, he was nonetheless willing to think ethnology as a form of geology. He spoke of concentric distribution areas, which featured 'cultural and national layering' that resembled the 'geological layering of the earth's crust' (Ratzel, 1891[1912]): 424). Like Charles Leyell before him, Ratzel established 'a geohistorical horizon [] into which questions of race and possibility [were] staged as self-evidently differentiated in time' (Yusoff, 2018: 77). He would for instance use an ethnographic map of the Crimean peninsula to illustrate his claim that one could find

'an occidental and frequently blond phenotype in the steep and rugged mountains and darker and thin-bearded Tartars in the steppe [...], whilst Turkic features would give way to Mongolic ones beyond the Isthmus of Perekop. At the same time the southern population would appear as agrarian whilst the northern and eastern one would be revealed as nomadic' (ibid).

Here, socio-economic behaviour was thus read in a geologic register in ways that would ring alarm bells to contemporary geographers.

It is important to stress that Ratzel's geologically driven environmentalism was not ecological in the way that we might imagine today. He may have had brief moments in which 
he lamented humanity's impact on the environment (Stehlin, 1988: xxiv), but it is crucial not to overstate this. Even though he operated with a notion of (slow) geologic agency, he did not contemplate that the earth system might be tipped into a state in which humanity would be driven to extinction.

In a story that is now widely familiar, Ratzel's political geography was popularised posthumously by the aforementioned Karl Haushofer (1869-1946), a General Major and National Socialist sympathiser. Haushofer's ideas in his role as editor of the Journal for Geopolitics (Zeitschrift für Geopolitik) formed a crucial milieu for the spread of geopolitical ideas in the $1920 s$, leading to an explosive preoccupation with questions of national survival and space. Like his intellectual hero, whom he had met in person as a child, Haushofer promoted a theory that sought to fuse geology, biology, anthropology, political science and sociology in an attempt to develop a holistic 'geographical' perspective. None of these disciplines were individually able to grasp the relationship between humanity and the earth. He deemed political science and sociology to be oblivious to the soil (bodenfremd) and compared them to architects who were ignorant of foundations (Haushofer, 1925: 89). Political geography, to Haushofer, was thus a necessary investigation of the way in which the cultural and political landscape had been shaped through geomorphology, geology, climate and the biosphere.

Whilst Haushofer was no expert in geology and attached less importance to it than Ratzel had, he did comment on the geological backdrop on which he saw history unfolding. Reflecting for instance on the political geography of the Rhineland in 1928, which at the time was under French occupation, Haushofer hypothesised that the volatile geology of the region had always made the Rhine a political fault line too - nature wanted 'no pacifism here' (Haushofer, 1928: 8). It is in moments like these that we encounter a geologic politics. Though predominantly two-dimensional, Haushofer's many maps would include information about the location of oil fields, seabed depth as well as ocean currents and winds. Occasionally, he would use raised-relief maps, which created a more vertical and less static imaginary, in which politically produced boundaries were seen to be shaped by what went on below and above the earth's surface (Haushofer, 1937). In this sense, both Ratzel and Haushofer's political geography was a human geography which sought to make arguments about the earth system's subtle agency.

Crucial to Haushofer's endeavour in particular was the aim of teasing out the military implications of this more-than-human geography, which he referred to as 'defence geopolitics' (Wehrgeopolitik). Not only was he interested in the military strategic significance of the biosphere, atmosphere and hydrosphere, but he also developed in his work a focus on the built environment. This entailed an ontological move, which he had inherited from Ratzel, to see the built and the physical environment as essentially one in their interaction with military actors. In the early 1940s, his gaze became increasingly drawn to subterranea. Whilst Ratzel had died before the ascent of the modern bunker, Haushofer lived in an era in which subterranean shelters, both military and civilian, were increasingly becoming vitally important. In 1934, he had still deemed French military fortifications a sign of a 'dead defence of space' (toter Raumschutz), which was inferior to a more Germanic 'vital will to space' (lebendiger Raumwille), an active defence, with 'plane, tank and firearm' (Haushofer 1934: 594). During WWII, however, he reversed this position considerably, writing with admiration of the ways in which British cities like London and Manchester had been prepared for aerial bombardment. 'An active air defence', he concluded, 'was the imperative of the day' (Haushofer, 1941: 152). Indeed, he called for an international law for the transformation of urban and rural landscapes into 'defence landscapes' (Wehrlandschaften) which would be able to protect both the population and industrial production.

In the early 1940s, Haushofer feared the annihilation of German cities through Allied bombing campaigns. Although he started to contemplate the geopolitical implications of 
urbicide, he had little time to reflect on the advent of nuclear warfare after the first atomic bombs were dropped on Japan in 1945. Haushofer would commit suicide in 1946 in an attempt to bury with him the German geopolitical tradition which had become inseparable from his name.

\section{In the country of last things}

A second wave of vertical thinking within the geopolitical tradition came about in the course of the nuclear revolution. The destruction of Hiroshima and Nagasaki brought home not just an understanding of the fragility of human existence in a nuclear armed world but also the need to harden core state structures against the threat of nuclear attack. Dalby (2013: 40) mentions this growing interest in subterranea during the Cold War but focuses on the activities of nuclear physicists, geophysicists and meterologists rather than geographers. Interestingly, he mentions in passing a revival of Ratzel's ideas in the work of US geopoliticians during the Cold War era (Dalby, 1990: 76).

In Germany, geopolitics was placed under something of a taboo after 1945. But even though politicians had to avoid its language, tainted as it was by its association with National Socialism, geopolitics experienced a stealthy renaissance. As I have shown in more detail elsewhere (Klinke, 2018), it was former Wehrmacht generals, now involved in setting up the new German army, navy and civil defence programme, who were still committed to a geopolitical worldview. Bitter about their defeat and anxious about Germany's shrunken territory and frontline position along the iron curtain, many of these men started publicising their ideas in the reborn Zeitschrift für Geopolitik. They were also increasingly interested in the earth, not just as the home of a nation's natural resources but as a possible retreat in an era of nuclear warfare. Whilst Lebensraum had been defined in horizontally territorial ways by Haushofer, it acquired a vertical dimension in the articles, pamphlets and books of this postwar generation of geopoliticians.

Heinz Guderian, a former Wehrmacht general and tank war strategist, warned in 1951 of a 'total war', which would be fought 'in depth, width and height of the battlespace, drawing in all relations of human life' (Guderian, 1951: 25). In the atomic age, he argued, there was a need for a new 'defence of the earth', which was to be achieved by the decentralisation and superhardening of vital industries. ' $[\mathrm{N}] \mathrm{o}$ house, no industrial plant, no railway station and no public building shall be built without an air-raid shelter', he claimed (18-19). Leo Geyr von Schweppenburg, also a panzer general and now resentful about the German defeat, hoped that (West) Germany could learn from the way in which the Soviet Union had hidden its armament production in subterranean structures (von Schweppenburg 1952). Erich Hampe, the first president of the Federal Agency for Civil Defence noted the role that 'subterranean shelters with considerable earthwork' had played in saving lives in Hiroshima (Hampe 1956: 48). His books were decorated not just by blueprints of underground civilian bunkers but by geopolitical maps which showed territorial borders, urban centres and bomber routes - thus combining the horizontal and vertical. In his words,

'medieval cities sought to protect their citizens through the construction of high and insurmountable walls. Today, the protection of the population has shifted underground' (6o).

Alexander Löfken, soon to be the head of the Federal Agency for Technical Relief (Technisches Hilfswerk), argued in a neo-Ratzelian mode that the nation's 'remaining living space' would have to be prepared for total war by including air-raid protection in every new built house (Löfken 1953; Löfken 1960). Lebensraum was now no longer primarily a territorial category. 
And whilst the aforementioned US geopoliticians Bowman, Kennan and Kissinger showed a remarkable disinterest in subterranea, a more vertical geopolitics did emerge in AngloAmerican nuclear strategy, too. Herman Kahn's 196o book On thermonuclear war argued against the strategy of mutually assured destruction (MAD) through the fictitious device of a 'doomsday machine', which would become immortalised in Stanley Kubrick's 1964 black comedy $\mathrm{Dr}$ Strangelove. Controversially, Kahn was convinced that even thermonuclear war was only a larger scale version of traditional war and could thus be won. Kahn was acutely aware of the need for subterranean fortifications, the location of which had to be kept secret. Hardening decreased the need to disperse such locations across a nuclear power's territory. Kahn promoted not just an expansive civil defence programme beneath American urban centres but also the conversion of mines into bunkers, which would provide 'radiation-protected working and living space' for the survivors of a nuclear war (Kahn, 1960[2007]: 517 emphasis added).

But geographers too had started to think the Cold War in vertical terms. In 1963, the American geographer Saul B. Cohen published an influential book under the title Geography and politics in a world divided, which remains a classic of geopolitical thought to this day. Although Cohen's analysis tended to linger on the earth's surface, it also drew on a more 3dimensional imagination which paid attention to the material properties of natural resources which could be found below ground, such as iron ore, petroleum, zinc or uranium. In his muscular and masculinist geopolitical imaginary,

' $[\mathrm{m}] \mathrm{an}$ can dam the Colorado and fill the Canyon with water if he is so disposed. He can, with nuclear energy, blast new holes of equal magnitude or fill present ones. He can bridge the Canyon or fly over it. If he desires and is willing to pay the price, man can move mountains. This is stressed not because man is likely to move many mountains, but to point out that nature only overpowers us with its immensity when we don't want to go through or over it' (Cohen, 1963[1973]: 5).

Cohen explained that space was 'multidimensional': it was 'horizontal as viewed from the standpoint of the shape, size, location, and natural resources of one political unit' and 'vertical as viewed from the interplay of man's objectives, laws, and economic and cultural tools upon the horizontal plane' ( 6 original emphasis). He also explained that the vertical cut across the existing grain of the national landscape, often providing opportunity for new forms of resource extraction (193). Although his maps were in $2 \mathrm{D}$, they did at times include vertical information, such as tunnels. Indeed, he was fascinated by the Mont Blanc car tunnel, as well as jumbo jets and low-cost airlines, the latter, or so he felt, enabled increasing numbers of North Americans and Europeans to experience transatlantic maritime space directly. He was absorbed too by various inter-continental pipeline projects and nuclear submarines, which highlighted to him the importance of understanding the depth of the oceans. Perhaps unsurprisingly, Cohen's book drew directly on Friedrich Ratzel's writings (39-40, 99, 134).

But the emergence of a subterranean geopolitics was not limited to West Germany and the United States. In 1970s, the British military strategist Colin S. Gray ( $\left.{ }^{*} 1943\right)$ had tried to adapt Mackinderian concepts to the atomic age (Gray, 1977). In 1980, he co-authored an infamous article, in which he and his collaborator Keith Payne argued that nuclear war, much like any other war, was winnable. They felt that Washington had become blinded by deterrence theory and the doctrine of massive retaliation, which they deemed strategically inflexible. Whilst Gray and Payne were willing to 'concede' that no US president should risk a nuclear war if the casualties amongst the US population were to be over 100 million, they proposed 'an intelligent offensive strategy, wedded to homeland defenses, which should reduce U.S. casualties to approximately 20 million' (Gray and Payne, 1980: 25). Interestingly, the authors also recommended that the United States develop a strategy to take out the command bunkers of the Soviet leadership, including those of the Soviet secret service, the KGB. Only two years after 
publishing the article in Foreign Policy, Gray would become an advisor to the Reagan administration.

By the time the Cold War ended, the underworld had firmly etched itself into the geopolitical imaginary. Even after the nuclear conflict between Washington and Moscow was declared over, Colin Gray and Geoffrey Sloan would hold on to the idea that geography was still 'the mother of all strategy' (Sloan and Gray, 1999: 3). Gray's 1999 book The Second Nuclear, concerned itself with subterranea in much the same way that the second generation of German Wehrmacht generals had done in the 1950s. '[D]eep underground basing of key military assets', he argued, was simply 'military common sense' (Gray, 1999: 86). But beyond that, he also reminded his readers that 'one should not be too hasty in recoiling in politically correct horror from the possibility of U.S. first use of nuclear weapons for "niche" war-fighting purposes'. The United States, he argued,

'should develop and acquire nuclear forces tailored not to ravage wide areas, but rather to effect the kind of damage to targets that other U.S. forces cannot impose reliably. Enemy military or political assets that are deep underground, whose position, though generally known, is not known precisely, or biological, toxin, and chemical agents that need to be vaporized should be at risk to U.S. nuclear weapons designed to penetrate the ground or to disable equipment over a wide area' (92).

\section{Conclusion}

This article has sought to sketch the history of geopolitical interest in the vertical or volumetric from the late $19^{\text {th }}$ to the late $20^{\text {th }}$ century. My focus has been on canonical figures associated with the western geopolitical tradition, though I recognise that other stories might be told about subterranean imaginaries in 'subaltern geopolitics' or in more 'popular' and 'practical' genres of geopolitical writing (Sharp, 1993; 2011). I have touched on the issue of technology, from steamboats to nuclear weapons, only in passing and recognise that a more thorough exploration of this question may help us understand better the socio-material context in which - and against which - geopolitical ideas were articulated. I hope that a discussion of the origins of these vertical geopolitical imaginaries (see also Adey, 2013: 52) opens up a number of further questions about the kind of things that a critically minded $21^{\text {st }}$ century vertical geopolitics should offer, both conceptually and politically. For if the vertical has long been a crucial vector of geopolitical thought, then classical geopolitics can neither simply be dismissed for its inherent flatness, nor can claims to the novelty of a volumetric geopolitics be made quite as confidentially as they have been in recent years. This insistence on the origins of a subterranean geopolitics may seem pedantic but there are, I would like to suggest, crucial implications.

The fact that there is a significant and unacknowledged pre-history to the idea of geopower in conservative and proto-fascist political geography implies that political questions are yet to be addressed in more detail by contemporary proponents of such ontologies (see also Klinke, 2019). How do we account for the vertical in ways that do not simply reproduce the gaze of classical geopolitics and the military strategic discourses that are so often found in close proximity? A simple description of techno-military assemblages, if done carelessly, may easily succumb to the kind of updates that security think tanks have long produced on the latest advances in defence technology. There are consequences too for the nature of geographical inquiry. Whilst it is difficult to disagree with Elden (2013a: 49) that geopolitics has in recent years 'become conflated with global politics or political geography writ large', it is worth noting that the tradition of geopolitical thought itself has fallen off the radar in political geography. As an analytical preoccupation with textual representation has become increasingly unfashionable, it seems that political geography's rich interrogation of its own trajectory is starting to be forgotten. Surely, a revamped geopolitics which draws on architectural theory and various new 
materialisms does not necessarily have to entail some kind of collective amnesia as to the origins and history of the geopolitical tradition.

Finally then, a note of caution against a tendency to fetishise the underground as a space from which deeper knowledge, geopolitical or otherwise, can be extracted. The language of 'excavation', 'unearthing' and 'revelation' which has crept into contemporary debates suggests that geographers are sliding back into the long-abandoned language of positivism. It is not that a subterranean geopolitics allows us to miraculously look under the carpet whose dull pattern we have previously been confined to describe. And whilst it may be impossible to live a life that is unaffected by geological forces and subterranean spaces, this does not mean that there is something deeper or more meaningful about those forces and spaces. Neither is subterranea some kind of collective unconscious in which repressed thoughts and urges are routinely cast, however much the example of toxic waste disposal may seem to confirm such an interpretation. Repression takes place every day in bright daylight. The logic of survival and mass destruction which gave birth to the subterranean ballistic missile silo and the fallout shelter was itself rooted in a powerful geopolitical imagination, which was developed in plain sight by mere terrestrials, even if some of those earthlings were driven by an interest in the underground. What gets lost in the reading of subterranean space as a dark counter- or underworld is the degree to which it has been moulded by human fantasies of conquest, extraction and domination. Maybe it is no surprise then that travel writers and adventurers who attend to the material worlds beneath our feet tend to find these worlds intensely peopled. 


\section{Bibliography}

Adey, P. (2013) 'Securing the volume/volume: Comments on Stuart Elden's plenary paper "Secure the volume"' Political Geography 34: 52-54

Adey, P., Whitehead, M. and Williams, A. J. (2013) From above: War, violence and verticality (London Hurst)

Anthony, P. (2016) 'Vertical thinking un the time of Humboldt' Blog-Netzwerk für Forschung unf Kultur, at https://blog.sbb.berlin/vertical-thinking-in-the-time-of-humboldt/ [accessed 7 March 2019]

Barry, A. and Gambino, E. (2019) 'Pipeline geopolitics: Subaquatic materials and the tactical point' Geopolitics [online first]

Bishop, R. (2012) 'Project "transparent earth" and the autoscopy of aerial targeting: The visual geopolitics of the underground' Theory, Culture E Society 28: 270-286

Bowman, I. (1942) 'Geography vs. geopolitics' Geographical review 32: 646-658

Childs, J. (2018) 'Extracting in four dimensions: Time, space and the emerging geo(-)politics of deep-sea mining' Geopolitics [online first]

Clark, N. (2013a) 'Geopolitics of the threshold' Political Geography 37: 48-50

Clark, N. (2013b) 'Geoengineering and geologic politics' Environment and Planning A 45(12): $2825-2832$

Clark, N. (2017) 'Politics of strata' Theory, Culture E Society 211-231

Cohen, S. B. (1963[1973]) Geography and politics in a world divided, $2^{\text {nd }}$ edition (New York: Oxford University Press)

Dalby, S. (1990) Creating the Second Cold War: The Discourse of Politics (London: Pinter)

Dalby, S. (2013) 'The geopolitics of climate change' Political Geography 37: 38-47

Deleuze, G. and Guattari, F. (1994) What is philosophy? (London: Verso)

Dittmer, J. (2014) 'Geopolitical assemblage and complexity' Progress in Human Geography 38: 385-401

Dittmer, J. (2017) Diplomatic material: Affect, assemblage and foreign policy (Durham: Duke University Press)

Dodds, K. (2019) Geopolitics: A very short introduction, $3^{\text {rd }}$ edition (Oxford: Oxford University Press)

Elden, S. (2010) 'Reading Schmitt geopolitically', Radical Philosophy 161: 18-26

Elden, S. (2013a) 'Secure the volume: Vertical geopolitics and the depth of power', Political Geography 34: 35-51

Elden, S. (2013b) 'Leibniz and geography: geologist, paleontologist, biologist, historian, political theorist and geopolitician' Geographica Helvetica 68: 81-93

Farish, M. (2004) 'Another anxious urbanism: simulating defence and disaster in Cold War America', in Graham, S. (ed.) Cities, war, and terrorism (Oxford: Blackwell): 93-109

Flint, Colin (2012) Introduction to geopolitics (London: Routledge)

Fluri, J. (2011) 'Bodies, bombs and barricades: Geographies of conflict and civilian (in)security' Transactions of the Institute of British Geographers 36: 280-296 
Garrett, B. L. (2013) Explore everything: Place-hacking the city (London: Verso)

Garrett, B. L. and Klinke, I. (2019) 'Opening the bunker: function, materiality, temporality' Environment and Planning $C$ [online first]

Graham, S. (2004) 'Vertical geopolitics: Baghdad and after' Antipode: A radical journal of Geograhy 36: 12-23

Graham, S. (2016) Vertical: The city from satellites to bunkers (London: Verso)

Gray, C. (1977) The geopolitics of the nuclear era: Heartlands, rimlands, and the technological revolution (New York: National Strategy Information Center)

Gray, C. and Payne, K. (1980) 'Victory is possible’ Foreign Policy 39: 14-27

Gray, C. S. (1999) The Second Nuclear Age (Boulder: Lynne Rienner)

Gregory, D. (2011a) “'Doors into nowhere” Dead cities and the natural history of destruction', in Meusburger, P., Heffernan, M. and Wunder, E. (eds.) Cultural memories (Heidelberg, Springer): 249-283

Gregory, D. (2011b) 'From a view to a kill: Drones and late modern war' Theory, Culture and Society 28: 188-215

Grosz, E. (2012) ‘Geopower’ Environment and Planning D 30: 973-975

Grosz, E., Yusoff, C. and Clark, N. (2017) 'An interview with Elizabeth grosz: Geopower, inhumanism and the biopolitical' Theory, Culture E Society 34: 129-146

Guderian, H. (1951a) So geht es nicht! Ein Beitrag zur Frage der Haltung Westdeutschlands. (Göttingen: IM Plesse)

Hampe, E. (1956) Im Spannungsfeld der Luftmächte: Eine Einführung in Luftgefahr und Bevölkerungsschutz (Köln: Maximilian-Verlag Köln)

Haushofer, K. (1925) 'Politische Erdkunde und Geopolitik', in E. Drygalski (Hg.) Freie Wege vergleichender Erdkunde (München und Berlin: Druck und Verlag von R. Oldenbourg): 86-103

Haushofer, K. (1928) 'Rheinische Geopolitik', in K. Haushofer (ed.) Der Rhein: Sein Lebensraum/sein Schicksal, 1. Band: Erdraum und Erdkräfte (Berlin: Kurt Vowinckel Verlag 1928): $1-16$

Haushofer, K. (1934) 'Geopolitische Grundlagen', in H.-A. Jacobsen (ed.) Karl Haushofer: Leben und Werk Band I (Boppard: Harald Boldt Verlag): 558-606

Haushofer, K. (1937) Weltmeere und Weltmächte (Berlin: Zeitgeschichte Verlag)

Haushofer, K. (1941) Wehrgeopolitik: Geographische Grundlagen einer Wehrkunde, 4. Und 5. Auflage (Berlin: Junker und Dünnhaupt)

Hawkins, H. (2018) “'A volcanic incident”: Towards a geopolitical aesthetics of the subterranean' Geopolitics [online first]

Hunt, W. (2019) Underground: A human history of the worlds beneath our feet (London: Simon and Schuster)

Kahn, H. (1960[2007]) On thermonuclear war (New Bruswick and London: Transaction)

Kearns, G. (2009) Geopolitics and Empire: The Legacy of Halford Mackinder (Oxford: Oxford University Press)

Kennan, G. F. (1947) 'The sources of Soviet conduct' Foreign Affairs 25: 566-582

Kissinger, H. A. (1957[1969]) Nuclear Weapons and Foreign Policy (Toronto: W. W. Norton and 


\section{Company)}

Kjellén, R. (1920) Grundriss zu einem System der Politik (Leipzig: S. Hirzel Verlag)

Klinke, I. (2018) Cryptic concrete: A subterranean journey into Cold War Germany (Oxford: Blackwell)

Klinke, I. (2019) 'Vitalist temptations: Life, earth and the nature of war' Political Geography 72: 1-9

Klinke, I. and Bassin, M. (2018) 'Lebensraum and its discontents' Journal of Historical Geography 61: $53-58$

Löfken, A. (1953) 'Grossraumplanung und Luftschutz', Ziviler Luftschutz, 18(12), pp. 282-283.

Löfken, A. (1960) 'Überleben in Schutzraumbauten’, Ziviler Luftschutz, 24, 5, 162-168.

MacDonald, F. (2008) 'Space and the atom: On the popular geopolitics of Cold War rocketry' Geopolitics 13: 611-634

MacFarlane, R. (2019) Underland: A deep time journey (London: Penguin)

Mackinder, H. (1900) 'A journey to the summit of Mount Kenya, British East Africa' The Geographical Journal 15: 453-476

Mackinder, H. (1902) Britain and the British Seas (London: William Heinemann)

Mackinder, H. (1904) 'The geographical pivot of history', The Geographical Journal 23: 421-444

Mackinder, H. (1919[1942, reprinted 2009]) Democratic ideals and reality: A study in the politics of reconstruction (London: Faber and Faber)

Mackinder, H. (1943) 'The round world and the winning of peace' Foreign Affairs 21: 595-605

Mahan, A. T. (1890[1980]) The influence of sea power upon history 1660-1805 (London: Bison)

Murrey, A. (2015) 'Invisible power, visible dispossession: The witchcraft of a subterranean pipeline' Political Geography 47: 64-67

Natter, W. (2005) 'Friedrich Ratzel's spatial turn', in H. van Houtum, O. Kramsch, and W. Zierhofer (eds.) B/ordering space (Aldershot: Ashgate): 171-87.

Ó Tuathail, G. (1996) Critical Geopolitics: The Politics of Writing Global Space (Minneapolis: University of Minnesota Press)

Peters, K. Steinberg, P. \& Stratford, E. (2018) Territory beyond terra (London: Rowman and Littlefield International)

Ratzel F, (1897[1923]) Politische Geographie (München und Leipzig: R. Oldenbourg)

Ratzel, F. (1881). Die Erde in vierundzwanzig gemeinverständlichen Vorträgen über Allgemeine Erdkunde (Stuttgart: J. Engelhorn)

Ratzel, F. (1882) Anthropogeographie Erster Teil: Grundzüge der Anwendung der Erkunde auf die Geschichte (Stuttgart: J. Engelhorns)

Ratzel, F. (1884) Wider die Reichsnörgler: Ein Wort ur Kolonialfrage aus Wählerkreisen (München: R Oldenbourg)

Ratzel, F. (1890[1906]) 'Über die anthropogeigraphischen Begriffe Geschichtliche Tiefe und Tiefe der Menschheit', in H. Helmoldt (ed.) Kleine Schriften Zeiter Band (München und Berlin: R. Oldenbourg): 215-236

Ratzel, F. (1891[1899]) Anthropogeographie Zweiter Teil: Die geographische Verbreitung des Menschen (Stuttgart: J. Engelhorns) 
Ratzel, F. (1891[1912]) Anthropogeographie Zweiter Teil: Die geographische Verbreitung des Menschen (Stuttgart: J. Engelhorns)

Ratzel, F. (1896) The History of Mankind, Volume 1 (London: MacMillan)

Ratzel, F. (1898[1906]) 'Die deutsche Tiefsee-Expedition', in H. Helmoldt (ed.) Kleine Schriften Zeiter Band (München und Berlin: R. Oldenbourg): 382-390

Ratzel, F. (1900[1911]) Das Meer als Quelle der Volksgrösse: Eine politisch-geographische Studie (Munich and Berlin: R. Oldenbourg)

Ratzel, F. (1901[2018]) 'Lebensraum: A biogeographical study, translated into English by Tul'si (Tuesday) Bhambry' Journal of Historical Geography 61: 59-80

Ratzel, F. (1902). Die Erde und das Leben, 1. Band (Leipzig und Wien: Bibliographisches Institut)

Ratzel, F. (1973) Wandertage eines Naturforschers. 1. Theil: Zoologische Briefe vom Mittelmeer. Briefe aus Süditalien (Leipzig: Brockhaus)

Schmitt, C. (1942[2015]) Land and sea: A world-historical mediation (Candor: Telos)

Schmitt, C. (1950[1997]) Der Nomos der Erde im Völkerrecht des Jus Publikum Europaeum. Stuttgart: Klett Cotta.

Scott, H. V. (2008) Colonialism, landscape and the subterranean' Geography Compass 2: 18531869

Sharp, J. (1993) 'Publishing American identity: Popular geopolitics, myth and the Reader's Digest' Political Geography 12: 491-503

Sharp, J. (2011) 'A subaltern critical geopolitics of the war on terror: Postcolonial security in Tanzania' Geoforum 42: 297-305

Shaw, I. (2016) Predator empire: Drone warfare and full spectrum dominance (Minneapolis: Minnesota University Press)

Slesinger, I. (2018) 'A cartography of the unknowable: Technology, territory and subterranean agencies in Israel's management of the Gaza tunnels' Geopolitics [online first]

Sloan, G. and Gray, C. (1999) 'Why geopolitics?' The Journal of Strategic Studies 22: 1-11

Smith, W. (1980) 'Friedrich Ratzel and the origins of Lebensraum' German Studies Review 3: 5168

Squire, R. and Dodds, K. (2019) 'Introduction to the special issue: Subterranean geopolitics' Geopolitics [online first]

Squire, V. (2016) 'Rock, water, air and fire: Foregrounding the elements in the Gibraltar-Spain dispute' Environment and Planning D 34: 545-563

Stehlin, S. (1988) 'Introduction', in F. Ratzel (1876[1988]) Sketches urban and cultural life in North America, New Brunswick and (London: Rutgers University Press): xiii-xxiv

Valdivia, G. (2015) 'Oil frictions and the subterranean geopolitics of energy regionalisms' Environment and Planning A 47: 1422-1439

von Schweppenburg, L. (1952) Die große Frage: Gedanken über die Sowjetmacht (Homburg: Bernhard und Graefe)

Weizman, E. (2002) 'Introduction to the politics of verticality', 23 April 2002, at https://www.opendemocracy.net/ecology-politicsverticality/article 801.jsp [accessed 21 September 2018].

Weizman, E. (2007) Hollow land: Israel's architecture of occupation (London: Verso) 
Werber, N. (2014) Geopolitik zur Einführung (Hamburg: Junus)

Williams, A. (2013) 'Re-orienting vertical geopolitics' Geopolitics 18: 225-246

Yusoff, C. (2018) A billon black anthropocenes or none (Minneapolis: Minnesota University Press)

Zhang, C. (2018) 'Mobile borders and turbulent mobilities: Mapping the geopolitics of the Channel Tunnel' Geopolitics [online first] 